\title{
Giant Cell
}

National Cancer Institute

\section{Source}

National Cancer Institute. Giant Cell. NCI Thesaurus. Code C12607.

An abnormally large cell that contains multiple nuclei and an abundant amount of cytoplasm. 